\title{
PLASMA NITRIC OXIDE STATUS IN PATIENTS WITH DRUG-INDUCED ACUTE RENAL FAILURE
}

\author{
BY \\ Ghada M. H. El-Kannishy, Ibrahim A. Abdel-Aal * \\ Heba Gamal ** and Abdel-Aziz Ghanem **** \\ Departments of hiternal Medicine, *Ctinical Pathology and \\ *** Forensic Medicine and Clinical Toxicology: Faculty of Medicine, Mansoura University, \\ ** Forensic Medicine and Toxicology, Faculty of Medicine, Cairo University, Egypi
}

\begin{abstract}
Background: Drug-induced acute renal failure $(A R F)$ is a medical problem affecting hospitalized patients and patients presented to emergency hospitals. A drug can induce ARF through a prerenal or an intrarend pathway. Subjects and methods: 12 patients with prerenal ARF and 7 patients with intrarenal nephrotoxic ARF were enrolled in the present study. They were clinically examined and laboratory and radiologically investigated. History of prescribed nephrotoxic medications, rise in serum creatinine levels and ARF manifestations were encountered in all cases. Plasma NO metabolites $\left(\mathrm{NO}_{2}\right.$ and $\left.\mathrm{NO}_{3}\right)$ were determined colorimetrically as a colored azo dye product of Griess reaction. Results: The study showed that nonsteroidal anti-inflammatory agents $(41.6 \%)$, angiotensin converting enzyme inhibitors (16.6\%) and sildenafil citrate, $(8.3 \%)$ were the single drug-induced prerenal ARF. The remaining cases $(33.3 \%)$ gave history of multiple drugs intake. On the other hand, aninoglycoside nephrotoxicity occurred in $14.3 \%$ of intrarenal ARF patients while, analgesics andlor anti-pyretics caused ARF in, 57.14\%. At the some time, intrarenal ARF was detected in association with methicillin or cephalosporin administration in the remaining patients $(28.6 \%)$. The onset of ARF in both series of patients began between four days and two weeks afier drug intake (except with sildenafil citrate) while the severity and prognosis were dose-dependent. Plasma NO.2 concentrations among intrarenal ARF patients were not significanlly differen from those observed in controls. Alsernatively, the concentration of plasma total NO-3 (NOX) anong prerenal ARF patients were significantly higher than controls. In addition, plasma NO-2 and NOx Concentrations of intrarenal ARF were significantly lower than those of prerenal ARF. Conclusion: Plasma total NO-3 (NOx) differentiates between prerenal (high) and intrarenal (normal or low) nephrotoxici1y. Hyperkalemia and relatively subiormal NO bioactivity found in intrarenat ARF may explain the high incidence of cardiovascular strokes in them. On the other hand, the excess NO in prerenal ARF participates in development of hypotension and collapse. Discontinuation of the responsible drug is ofien the only necessary management while avoidance of these drugs is the most effective way to avoid drug-
\end{abstract}


induced nephroloxicity.

Key words: ARF: acute renal failure; GFR: glumerular filtration rafe ATN: acute tubular necrosis; NOS: nitric oxide synthase: (i: induced; $e$ : endothelium; $c$ : constimutive; n: neural;) ADMA:asymmetric dimethylarginine.

\section{INTRODUCTION}

Nephrotoxicity is a major side effect in clinical practice, which frequently leads to acute renal failure (ARF). Drug-induced ARF is classified into two categories: (1) Prerenal ARF is a rapidly but commonly reversible uremia caused by renal hypoperfusion. In prernal ARF, there is a reduction in glomerular filtration rate (GFR) with no frank renal parenchymal damage. (2) Intrarenal ARF that may be due to prolonged renal hypoperfusion, resulting in tissue ischemia and acute tubular necrosis (ATN), or due to toxic damage of the nephrons. Any condition that causes prerenal ARF may progress to intrarenal ARF if renal hypoperfusion is severe and prolonged (Mindell and Chertow, 1997; Alexopoulos, 1998; Silva, 2004; Markowtiz and Perazella, 2005). The morbidity and mortality rates in drug-induced uremic patients with serum creatinine levels greater than $3.0 \mathrm{mg} / \mathrm{dl}$ remain high, although, a better survival rate in them is not a far hope (Nash et al., 2002).

Nitric oxide (NO) plays a major role in maintaining the high renal blood flow and is also involved in the regulation of glomerular hemodynamics and contractility of mesangial cells, not only under basal but also in toxic acute renal failure (Schramm et al., 1996). NO is critically involved in the functional and morphological alterations observed in drug-induced nephrotoxicity. In the majority of such conditions, NO synthesis appears elevated. The noted increase of NO synthesis appears primarily protective to the remaining renal function (Rivas-Cabanero et al., 1996 \& 1997; Mindell and Chertow, 1997; Stroes et al., 1997; Heman et al.,1998; Suschek et al., 2000). However, this increase in NO synthesis and release does not lead to renal vasodilatation, probably due to its decreased bioavailability through its rapid interaction with reactive oxygen species and the simultaneous increase in the release of vasoconstrictors (Goligorsky et al., 2004). Alternatively, decreased endothelium derived NO has been reported in acute renal failure that may be due to depletion of tetrahydrobioptrin, a cofactor for NOSs synthesis (Kakoki et al., 2000). In agreement with these latter findings is that $79 \%$ of uremic plasma inhibited both endothelial and inducible NOS activities while the remaining percent stimulated NOS activities (Arese et al., 1995). Altered generation of nitric oxide by the endothelial cells represents an important feature of 
endothelial dysfunction that contributes to the pathophysiology of acute renal injury (Goligorsky et al., 2002). So, it has been clearly demonstrated that $\mathrm{NO}$ participates in the pathogenesis of ARF and the issue of whether NO is a "good" or "bad" molecule in ARF is currently under extensive investigation (Valdivielso and Blantz, 2002).

The above review shows a controversy about NOS/NO metabolism in druginduced ARF in experimental models, while studies in this field on human are very rare. So, the present study was initiated to determine the concentration of plasma $\mathrm{NO}$ metabolites $\left(\mathrm{NO}_{-2}+\mathrm{NO}_{-3}\right)$ in patients with drug-induced ARF whether secondary to prerenal or intrarenal druginduced nephrotoxicity.

\section{SUBJECTS AND METHODS}

Serially hospitalized 19 patients with ARF were studied. Before the development of ARF, all these patients were healthy and none had a past history of renal disease. History of nephropathic drug intake was given by all patients. Cases with hemolytic crises, reaction to radio contrast media or hepatorenal failure were not included. On clinical background, none of the uremic patients gave a past history of chronic associating diseases (renal, pancreatic, hepatic, and endocrine disorders). Before investigations, any drug influencing the designed investigations were replaced by biochemically noneffective therapies.

The present study comprized 12 patients suffered from prerenal ARF and the remaining (7 patients) had intrarenal nephrotoxic ARF. No case with postrenal ARF was included in this study. A present history of drug intake, rise of serum creatinine levels, fluid and electrolyte imbalance and abnormal urine analysis results were the keystone of drug-induced ARF diagnosis. Diagnosis of the underlying cause of ARF was based on the history while clinical, radiological, and biochemical examinations pointed to the type and stage of ARF (Schrier et al., 2004). Prerenal ARF due to drug intake is caused by renal hypoperfusion and reduction in glomerular filtration rate without renal parenchymal damage (low effective circulating volume). In contrast, intrarenal drug-induced ARF reflects damage of the nephrons by drug(s) due to prolonged hypoperfusion or directly to their toxic damage.

In addition, 10 healthy persons selected from patients' relatives, blood donors or hospital workers were similarly studied as a reference (control) group. They were matched in age, sex and body mass index (BMI) with the uremic patients.

Informed consent was obtained from all subjects (patients and controls). 
Laboratory investigations:

a- Serum and urinary creatinine $(\mathrm{Cr})$, spectrophotometric end point assay (BioMerieux-Vitek Inc., 595 Anglurn Drive Hazeiwood, Missouri 630422395 USA).

b- Serum and urinary $\mathrm{Na}$ and $\mathrm{K}$ by ion selective electrode (AVL-ISE analyzer 988-3,4 Switzerland).

c- Fractional excretion of sodium (FENa) \% that measures the activity of the kidneys in resorbing sodium was calculated (Mindell and Chertow, 1997) = (urine $\mathrm{Na} \times$ serum $\mathrm{Cr}$ ) / (urine Cr $\times$ serum Na) $\times 100$.

d- Plasma (EDTA) nitric oxide metabolites $\left(\mathrm{NO}_{2} / \mathrm{NO}_{3}\right)$ were determined by photometric assay (Moshage et al., 1995) using byproducts of Assay.Designs. Inc. (800 Technology Drive Ann Arbor, MI:48108 USA).

Data being parametric, statistical analysis for each group results were presented as mean \pm SD. Statistical data of each group of patients were compared with each other and with those for healthy subjects using the Student $t$ test. The significance for any of these tests was set at $P<0.05$ (Knapp and Miller, 1992). Statistical analyses were performed with SPSS 9.0 (SPSS, Inc., Chicago, IL USA).

\section{RESULTS}

(A) Demographic data of the studied cases:

In the total ARF group (19 patients) and the normal control group (10 subjects), the male to female ratios were $12: 7$ and $6: 4$ while the mean ages were $44.9 \pm 7.7$ and $45.3 \pm 4.8$ years and BMI mean values were $24.1 \pm 2.5$ and $25.0 \pm 1.3$ respectively.

(B) The main clinical and laboratory data are shown in Tables from 1 to 5 .

\section{DISCUSSION}

Drug-induced ARF is one of the common problems seen by nephrologists in emergency hospitals, but its true frequency is probably underestimated. Diagnosis of it is typically only made in uremic patients without another explanation for deteriorating renal function, and is often proved by improvement after drug withdrawal. Failure to recognize drug nephrotoxicity and discontinuation of the offending agent(s) may result in unnecessary morbidity and occasionally, irreversible acute renal failure (Evenepoel, 2004). Despite the progress in pharmaco-therapy, the frequency of hospital acquired druginduced acute renal failure has increased from less than $5.0 \%$ (Mindell and Chertow, 1997) to $6.4 \%$ (Nash et al., 2002) of the total ARF affections. More distressing is the finding that mortality associated 
with drug-induced acute renal failure has remained high (Nash et al., 2002).

In the present study, the onset of ARF was related to drug therapy, oftenly reversible specifically in prerenal cases and the severity was dose dependent. These results agree with many studies (Alexopoulos, 1998; Evenepoel, 2004; Markowtiz and Perazella, 2005). Prerenal ARF (Table 1) was found to be induced by nonsteroidal anti-inflammatory agents (41.6\%), angiotensin converting enzyme inhibitors $(16.6 \%)$ and sildenafil citrate $(8.3 \%)$. The remaining $(33.3 \%)$ was due to combination of drugs. The prerenal changes were peripheral vasodilatation, interference with fluid and electrolyte homoestasis and adverse cardiotoxic changes. Adverse renal effects of conventional nonsteroid antiinflammatory drugs occur because of inhibiting the synthesis of nonselective cyclooxygenase responsible for synthesis of prostaglandins which are important in the modulation of renal physiology (Gambaro and Perazella, 2003). At the same time, aminoglycoside intrarenal nephrotoxicity with ARF (Table 2) occurred in $14.3 \%$ of the investigated patients while combined antibiotics, analgesics and antipyretics caused $57.1 \%$ of intrarenal ARF. Administration of certain antibiotics (methicillin and cephalosporin like groups) induced intrarenal ARF in $28.6 \%$ of the studied series of patients. Some authors (Silva, 2004; Markowtiz and Perazella, 2005) noticed that all aminoglycosides had the potential to produce nephrotoxicity while others (Boffa et al., 2000) considered antibiotics, in general, as the most common cause of $\mathrm{ARF}$.

These drugs appear to be minimally metabolized within the body and undergo nearly exclusive renal excretion. The role of infection (when present) and subsequent bacterial endotoxin can influence the pathogenesis of drug-induced nephrotoxicity. The clinical course of drug nephrotoxity depends on the primary health status in these patients. In the present study, FENa \% (Table 3) was a reliable index for differentiation between both types of ARF. However, Mindell and Cherlow (1997) stated that there was an overlap in the values of FENa\% in ARF types. Thus, decreased $\mathrm{FENa} \%$ was noted in patients with decreased effective circulating fluid volume (Aromoff, 1992).

Cardiac manifestations recorded in this study were due to the noted hyperkalemia of ARF (Table 4). In the present study, full recovery was observed in $73.5 \%$ and incomplete recovery was found in only $16.0 \%$ while worsening of the condition with development of complications was encountered in $10.5 \%$ of cases. Factors of poor prognosis were a poor previous health status and the presence of hidden infection. Oligurea was a high risk of morbidity. 
Management of the present cases included: (1) stopping administration of the nephrotoxic drugs.(2) encouragement of intravenous fluid infusion for drug elimination (3) dialysis for intrarenal cases till renal function was restored and (4) proper management of any clinical disorder of the vital oryans (e.g. cardiovascular, neurovascular and pulmonary systems).

Endothelial dysfunction in ARF may result from accumulation of uremic toxins. These include a variety of guanidino compounds which have been shown to be nitric oxide synthase modulators both in vitro and in vivo (DeDeyn et al., 2003). Thuraisingham and Yaqoob (2003) reported that there was an increased NO release, but this was associated with excess consumption of it in uremia. NO metabolites (NOx) in the plasma of hemodialysis nephrotoxic patients showed higher concentrations, both pre- and post-dialysis compared to controls. This is not a simple retention by ARF since culture of endothelial cells in uremic plasma demonstrated increased $\mathrm{NO}$ release compared to controls. At the same time, Noiri and Colleagues (1996) concluded that, excess NO were produced via induced NOS (iNOS) in the course of acute renal failure and hemodialysis modified the state of plasma NOS activity in uremia. So plasma taken after hemodialysis session showed a reduced irhibitory activity since, molecules reducing NOS activity were accu- mulated in the ultrafiltrate.

In the present study, there was significantly higher concentrations of plasma NO stable metabolites in the form of total nitrates (NOx) in prerenal ARF patients compared to healthy control group (Table 5). The high plasma NOx concentrations can be attributed to the rapid inactivation of the excessively released NO. Moreover, it is likely that renal dysfunction may decrease clearance of such NO metabolites, amongst which NO-3. In this respect, Suto et al. (1995) showed that approximately $50 \%$ of the ingested nitrates are excreted in the urine. Subsequently, total nitates (NOx) will be retained in the circulation in cases with renal insufficiency. In this respect and based on pharmacological and experimental studies, some authors (Conger et al., 1995; Can et al., 2000) suggested an impaired production of plasma $\mathrm{NO}$ in ARF. Alternatively others (RivasCabanero et al., 1997) found that in ARF, NO is formed in excessive amounts due to an augmented expression of both iNOS and endothelial NOS (eNOS) but not neuronal NOS (n NOS). Altered generation of $\mathrm{NO}$ by endothelial cells or reduced $\mathrm{NO}$ bioavailability represents an important feature of endothelial dysfunction (Arese et al., 1995; Goligorsky et al., 2002). Conger et al. (1995) have demonstrated that vasorelaxation in response to stimuli generating endothelium-derived relaxing factor was inhibited in ARF. 
With regard plasma NOx concentration in intrinsic (intrarenal) ARF patients, it showed no significant difference from the control group. However, there was a significant decrease in comparison to the corresponding prerenal ARF value (Table 6). These findings can be explained by the possibility of NO conversion to peroxynitrite which is implicated in cytotoxicity. Of interest is that plasma NOx levels (obtained under condition of dietary nitrate control) do not give stand-alone information about NO production, particularly when renal function is impaired. Reduced synthesis of the vasoactive substances (e.g. NO and prustaglandins) in remal disease might predispose such patients to druginduced nephropathy. Subsequently, Can et al. (2000) postulated that L-argininc supplementation had beneficial effects in gentamycin-induced acute renal failure. The nitric oxide released from vascular endothelium played a protective role in gentamycin nephrotoxicity (Goto et al., 2004).

The result of the present study assumed an increased NO production in prerenal ARF and a decreased production of it in intrarenal affections. Both conditions are harmful for the corresponding patients' and contribute to the pathophysiological diverge seen in them. 
Table (1): The main medical data in prerenal ARF patients.

\begin{tabular}{|c|c|c|c|c|c|}
\hline \multicolumn{2}{|c|}{ Cases } & \multirow[b]{2}{*}{ Pre existing disease } & \multirow{2}{*}{ Prescribed drug } & \multirow{2}{*}{$\begin{array}{l}\text { Duration of } \\
\text { therapy }\end{array}$} & \multirow{2}{*}{$\begin{array}{l}\text { Major } \\
\text { presenting signs } \\
\text { and symptoms }\end{array}$} \\
\hline No. & $\%$ & & & & \\
\hline 5 & 41.6 & $\begin{array}{l}\text { Autominmune diseases- } \\
\text { ostcoartheritis }\end{array}$ & $\begin{array}{l}\text { Non steroidal anti- } \\
\text { inflammatory }\end{array}$ & 4 days & \multirow{4}{*}{$\begin{array}{l}\text { - Hypotension, } \\
\text { Collapse and } \\
\text { cardiovascular } \\
\text { incompetence } \\
\text { - Acule renal failure }\end{array}$} \\
\hline 2 & 16.6 & Hypertension & $\begin{array}{l}\text { Angiotensin converting } \\
\text { enzyme inhibitor }\end{array}$ & .4 days & \\
\hline 1 & 8.3 & Senile impotence & Slidenafil citrate & 2 hours & \\
\hline 4 & 33.3 & $\begin{array}{c}\text { Prolonged unknown } \\
\text { fever }\end{array}$ & $\begin{array}{l}\text { Mixed drugs (antibiotics, } \\
\text { antipyretics and } \\
\text { analgesics) }\end{array}$ & 4 days & \\
\hline
\end{tabular}

Table (2): The main medical data in intrarenal ARF patients.

\begin{tabular}{|c|c|c|c|c|c|}
\hline \multicolumn{2}{|c|}{ Cases } & \multirow[b]{2}{*}{ Pre exisling distase } & \multirow[b]{2}{*}{ P'rescribud drug } & \multirow{2}{*}{$\begin{array}{c}\text { Duration of } \\
\text { therapy }\end{array}$} & \multirow{2}{*}{$\begin{array}{c}\text { Major presenting } \\
\text { signs and } \\
\text { symproms }\end{array}$} \\
\hline No. & $\%$ & & & & \\
\hline \multirow{2}{*}{$\begin{array}{l}1 \\
2\end{array}$} & 14.3 & \multirow{2}{*}{$\begin{array}{l}\text { Urinary tract infection } \\
\text { Prolonged unknown } \\
\text { fever }\end{array}$} & \multirow{2}{*}{$\begin{array}{c}\text { Aminoglycoside } \\
\text { Methicillin and } \\
\text { cephalosporin antibiotics }\end{array}$} & 14 days & \multirow{3}{*}{$\begin{array}{l}\text { (1) Hypersensilivity } \\
\text { reaction. } \\
\text { (2) Normotensive } \\
\text { (3) Urinary volume } \\
\text { depletion and } \\
\text { urinary deposit } \\
\text { of RBCs and } \\
\text { casts. } \\
\text { (4) ARF }\end{array}$} \\
\hline & 28.6 & & & $7 \& 10$ days & \\
\hline & 57.1 & Variable & Multiple drugs & 8-12 days & \\
\hline
\end{tabular}


Table (3): Data of significance in urine analysis of both ARF groups.

\begin{tabular}{|c|c|c|}
\hline & Prerenal & Intrinsic ARF \\
\hline Specific gravity & -1.020 & 1.010 (fixed) \\
\hline FENa\% & $<1.0$ & $>1.0$ \\
\hline Albuminurea & Nil - trace & ++ \\
\hline Casts & Hyaline (few) & Epithelial \& Granular \\
\hline
\end{tabular}

Table (4): Selected kidney function tests (serum creatinine, sodium and potassium concentrations) statistical data in normal control group versus ARF patients.

\begin{tabular}{|c|c|c|c|}
\hline Data & $\begin{array}{c}\text { Creatinine } \\
\mathrm{mg} / \mathrm{dl}\end{array}$ & $\begin{array}{c}\text { Sodium } \\
\mathrm{mmol} / \mathrm{l}\end{array}$ & $\begin{array}{c}\text { Potassium } \\
\mathrm{mmol} / \mathrm{l}\end{array}$ \\
\hline Normal control & $1.05 \pm 0.2$ & $137.1 \pm 4.4$ & $3.90 \pm 0.4$ \\
\hline ARF patients & $6.8 \pm 1.5$ & $136.6 \pm 3.8$ & $5.15 \pm 1.7$ \\
\hline p-value & $<0.001$ & $>0.90$ & $<0.001$ \\
\hline
\end{tabular}


Table (5): Statistical data of plasma $\mathrm{NO}$ stable metabolites as $\mathrm{NO}_{2}$ and $\mathrm{NO} \times\left(\mathrm{NO} 2+\mathrm{NO}_{3}\right)$ in the studied groups.

\begin{tabular}{|l|c|c|c|}
\hline Items (studied groups) & $\mathrm{NO}_{x} \mu \mathrm{mol} / \mathrm{L}$ & $\mathrm{NO}_{2} \mu \mathrm{mol} / \mathrm{L}$ \\
\hline [A] Normal control group & $\mathrm{X} \pm \mathrm{SD}$ & $36.2 \pm 6.3$ & $11.4 \pm 1.5$ \\
\hline [B] Prerenal ARF group & $\mathrm{X} \pm \mathrm{SD}$ & $49.5 \pm 8.3$ & $12.2 \pm 1.8$ \\
\hline [C] intrarenal ARF group & $\mathrm{X} \pm \mathrm{SD}$ & $32 \pm 9.5$ & $10.5 \pm 2.4$ \\
\hline P: A versus B & & 0.001 & 0.624 \\
\hline P: A versus C & & 0.567 & 0.345 \\
\hline P: B versus C & 0.001 & 0.012 \\
\hline
\end{tabular}




\section{REFERENCES}

Alexopoulos, E. (1998) : "Drug-induced acute interstitial nephritis". Ren. Fail., 20: 809-19.

Arese, M.; Strasly, M.; Ruva, C.; Costamagna, C.; Ghigo, D.; MacAllister, R.; Verzetti, G.; Tetta, C.; Bosia, A. and Bussolino, F. (1995): "Regulation of nitric oxide synthesis in uraemia". Nephrol. Dial. Transplant., 10: 1386-97.

Aromoff, G. R. (1992) : "Nonsteroidal anti-inflammatory drug induced renal syndromes". J. Ky. Med. Assoc., 90: 336-9.

Boffa, J. J.; De preneuf, H.; Bouadma, L.; Daudon, M. and Pallot, J. L. (2000) : "Acute renal failure after amoxicillin crystallization". Presse. Med., 29: 699-701.

Can, C.; Sen, S.; Boztok, N. and Tuglular, I. (2000) : "Protective effect of oral Larginine administration against gentamicin-induced renal failure in rats". Eur. $J$. Pharmacol., 390:327-334.

Conger, J.; Robinette, J.; Villar, A.; Raij, L. and Shultz, P. (1995) : "Increased nitric oxide synthase activity despite lack of response to endothelium-dependent vasodilators in postischemic acute renal failure in rats". J. Clin. Invest., 96: 631-8.

DeDeyn, P. P.; Vanholder, R. and
D'Hooge, R. (2003) : "Nitric oxide in uremia: effects of several potentially toxic guanidino compounds". Kidney Int. Suppl., 84: S25-8.

Evenepoel, P. (2004) : "Acute toxic renal failure". Best. Pract. Res. Clin. Anaesthesiol, 18 (1): 37-52.

Gambaro, G. and Perazella, M. A. (2003) : "Adverse renal effects of antiinflammatory agents: evaluation of selective and nonselective cyclooxygenase inhibitors". J. Intern. Med., 253: 643-52.

Goligorsky, M. S.; Brodsky, S. V. and Noiri, E. (2002) : "Nitric oxide in acute renal failure: NOS versus NOS". Kidney Int., 61: 855-61.

Goligorsky, M. S.; Brodsky, S. V. and Noiri, E. (2004) : "NO bioavailability, endothelial dysfunction, and acute renal failure: New insights into pathophysiology". Seminars in Nephrology, 24: 316-323.

Goto, T.; Fujigaki, Y.; Sun, D. F.; Yamamoto, T. and Hishida, A. (2004) : "Plasma protein extravasation and vascular endothelail nitric oxide synthase induction in gentamicin-induced acute renal failure in rats". Virchows Arch., 444: 362-74.

Kakoki, M.; Hirata, Y.; Hayakawa, H.; Suzuki, E.; Nagata, D.; Tojo, A.; Nishimatsu, H.; Nakanishi, N.; Hattori, Y.; 
Kikuchi, K.; Nagano, T, and Omata, M. (2000) : "Effects of tetrahydrobiopterin on endothelial dysfunction in rats with ischemic acute rena! failure". J. Am. Soc. Nephrol., 11: 301-9.

Knapp, R. C. and Miller, III, M. C. (1992) : Describing the Performance of a Diagnostic Test in Clinical Epidemiology and Biostatistic. Williams and Willkins, Maryland, USA.

Markowtiz, G. S. and Perazella, M. A. (2005) : "Drug-induced renal failure: a focus on tubulointerstitial disease". Clin. Chem. Acta., 351: 31-47.

Mindell, J. A. and Chertow, G. M. (1997) : "A practical approach to acute renal failure". Medical Clinics of North America, 81: 731-748.

Nash, K.; Hafeez, A. and Hou, S. (2002) : "Hospital acquired renal insufficiency". Am. J. Kidney Dis., (39): 930-6.

Noiri, E.; Peresleni, T.; Miller, F. and Goligorsky, M. S. (1996) : "In vivo targeting of inducible NO synthase with oligodeoxynucleotides protects rat kidney against ischemia". J. Clin. Invest., 97 (10):2377-83.

Rivas-Cabanero, L.; Rodriguez-Lopex, A. M.; Martinez-Salgado, C.; Saura, M.; Lamas, S. and Lopez-Novoa, J. M. (1997):
"Gentamicin treatment increases mesangial cell nitric oxide production". Exp. Nephrol., 5: 23-30.

Rivas-Cabanero, L.; Valdivielso, J. M.; Alonso, J. R.; Arevalo, M.; Eleno, N. and Lopez-Novoa, J. M. (1996) : "Increased glomerular nitric oxide synthesis in gentamicin-induced renal failure". Kidney Int., 50a: 1782.

Schramm, L.; Heidbreder, E.; Lopau, K.; Schaar, J.; Zimmermann, J.; Teschner, M.; Ling, H. and Heidland, A. (1996) : "Influence of nitric oxide on renal function in acute renal failure in the rat". Miner Electrolyte Metam., 22: 168-77.

Schrier, R. W.; Wang, W.; Poole, B. and Mitra, A. (2004) : "Acute renal failure: definitions, diagnosis, pathogenesis, and therapy". J. Clin. Invest., 114: 5-14.

Silva, F. G. (2004) : "Chemical-induced nephropathy: a review of the renal tubulointerstitial lesions in humans". Toxicol. Pathol., 32 (Suppl 2): 71-84.

Stroes, E. S.; Luscher, T. F.; de Groot, F. G.; Koomans, H. A. and Rabelink, T. J. (1997) : "Cyclosporine A increases nitric oxide activity in vivo". Hypertension, 29: 570-575.

Suschek, C. V.; Bonmann, E.; Kleinert, H.; Wenzel, M.; Mahotka, C.; Kol, H.; For- 
stermann, U.; Gerharx, C. D. and KoilbBachofen, V. (2000) : "Amphotericin B severly affects expression and activity of the endothelial constitutive nitric oxide synthase involving altered mRNA stability". Br. J. Pharmacol., 131: 473-481.

Suto, T.; Losonczy, G.; Qiu, C.; Hill, C.; Samsell, L.; Ruby, J.; Charon, N.; Venuto, R. and Baylis, C. (1995): "Acute changes in urinary excretion of nitrite + nitrate do not necessarily predict renal vascular NO production". Kidney Int., 48:.1272-7.

Thuraisingham, R. C. and Yaqoob, M. M. (2003) : "Oxidative consumption of nitric oxide: a potential mediator of uremic vascular disease". Kidney Int. Suppl., 84: S29-32.

Valdivielso, J. M. and Blantz, R. C. (2002) : "Acute renal failure: Is nitric oxide the bad guy?". Antioxidant \& Redox Signaling, 4: 925-934. 


\section{دراسة عن وضع أوكسيد النيتريك فيى بلإزهـا الدم فى حالات الفشل الكلوىى اللاد النانجة عن تعاطيى أدوية بلية}

$$
\text { المشتركون فى "البحث }
$$

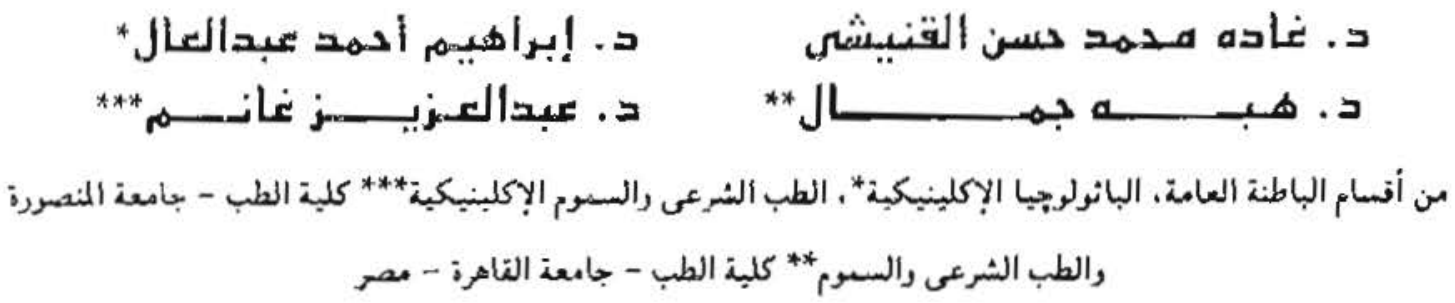

إن معدل حالات النشل الكلوى الحاد الناتج من تعاطى بعض الأدورة العلاجبية بالستشفيات تد إزداد إصورة ملحوظة، ومن بخمن الأدربة المودية للفشل الكلوى نأتى المضادات الحبيرية رالاستبريدات المفاد للالثهاب بصفة عامة من أهم الأسباب . لهذا كان الغرض من هذه الدراسة

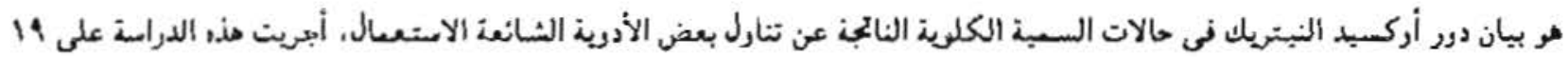

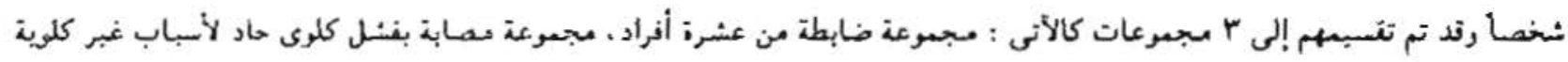

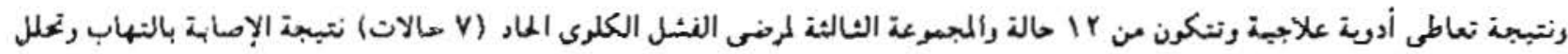

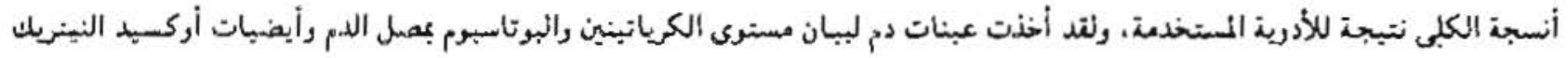
بالبلازما.

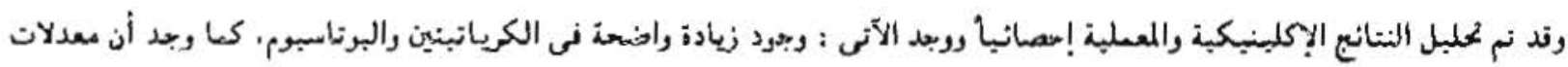

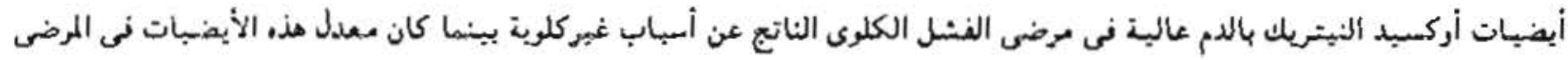

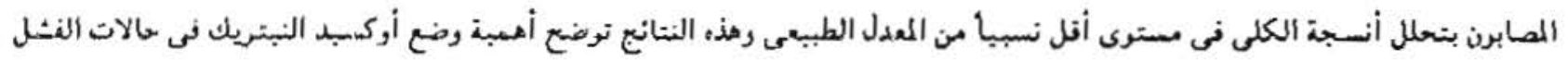

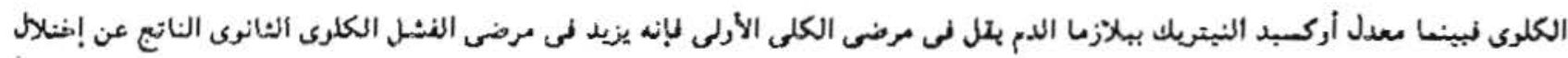
الدررة الدموية ، ومذا يوضح أسباب الاختلان الإكلينيكى فى ماتين المجسوعثين. 